\title{
Breast cancer: relation between quality of life and physical activity level
}

\section{Câncer de mama: relação entre qualidade de vida e nível de atividade física}

Marina Ribovski', Leonessa Boing', Fabiana Flores Sperandio,' Mirella Dias', Nycolle Martins Reis', Adriana Coutinho de Azevedo Guimarães ${ }^{1}$

\begin{abstract}
The objective was to investigate the relation between quality of life and physical activity level in women with breast cancer undergoing treatment at the Oncologic Research Center (CEPON). A total of 158 women (56 \pm 9 years) answered a structured questionnaire, at a standardized interview, about sociodemographic and clinical information; economic situation (IBGE - Instituto Brasileiro de Geografia e Estatística); physical activity (IPAQ - International Physical Activity Questionnaire); and quality of life (QLQ-C30 - Quality of Life Questionnaire; QLQ-BR23). Most of the women was not sufficiently active $(71.5 \%)$ and reported better global quality of life, with a score of $73 \pm 25$. There was a significant difference on the functional scale for the items physical function $(\mathrm{p}=0.007)$ and role performance $(\mathrm{p}=0.048)$, with better quality of life values for active women, as well as on the symptom scale for the items loss of appetite $(\mathrm{p}=0.005)$ and pain $(\mathrm{p}=0.040)$. There was a positive association between total physical activity and quality of life in physical function $(\mathrm{r}=0.23 ; \mathrm{p}=0.01)$ and role performance $(r=0.023 ; p=0.01)$ and a negative association in the symptom scale $(\mathrm{r}=-0.24 ; \mathrm{p}=0.01)$ and item loss of appetite $(\mathrm{r}=-$ $0.25 ; \mathrm{p}=0.01$ ). We conclude that women with breast cancer were not sufficiently active and showed good global quality of life scores, being that the actives presented better physical function, role performance and less loss of appetite and pain.
\end{abstract}

\section{Keywords}

Motor activity. Breast neoplasms. Quality of life.

\section{Resumo}

O objetivo foi investigar a relação entre qualidade de vida e nivel de atividade física de mulheres com câncer de mama em fase de tratamento no Centro de Pesquisas Oncológicas (CEPON). Um total de 158 mulheres (56 9 anos) respondeu ao questionário estruturado, em forma de entrevista, sobre características sociodemográficas e clínicas; situação econômica (IBGE - Instituto Brasileiro de Geografia e Estatística); atividade física (IPAQ - International Physical Activity Questionnaire) e qualidade de vida (QLQ-C30 - Quality of Life Questionnaire; QLQ-BR23). A maioria das mulheres era insuficientemente ativa $(71,5 \%)$ e relatou melhor qualidade de vida geral, com escore de $73 \pm 25$. Houve diferença significativa na escala funcional para os itens função física $(p=0,007)$ e desempenho de papéis ( $p=0,048)$ com valores mais próximos de uma melhor qualidade de vida para as ativas, bem como na escala sintomática para os itens perda de apetite $(p=0,005)$ e dor $(p=0,040)$. Houve associação positiva entre atividade física e qualidade de vida na função física $(r=0,23 ; p=0,01)$ e desempenho de papéis $(r=0,023 ; p=0,01)$ $e$ associação negativa na escala sintomática $(r=-0,24 ; p=0,01) e$ item perda de apetite $(r=-0.25 ; p=0.01)$. Conclui-se que as mulheres com câncer de mama eram insuficientemente ativas e apresentavam bons escores de qualidade de vida geral, sendo que as ativas apresentaram melhor função física, desempenho de papéis e menor presença de sintomas, perda de apetite e dor.

\section{Palavras-chave}

Atividade motora; Neoplasias da mama; Qualidade de vida.

\section{Introduction}

Cancer is unquestionably a public health problem worldwide ${ }^{1}$. According to the International Agency for Research on Cancer (IARC) $)^{2}$, the number of new cancer cases in the world will increase by $57 \%$ in 20 years. The Brazilian National Cancer Institute (INCA) ${ }^{3}$ estimates there will be around 600 thousand new cases of cancer in 2016/17, highlighting breast cancer (BC), the third most prevalent in the Brazilian

1 Universidade do Estado de Santa Catarina. Centro de Ciências da Saúde e do Esporte. Departamento de Educação Física. Florianópolis, SC. Brazil. population, with an expected 57,960 new cases $^{3}$. In the South of the country, the forecast is for an average of 74.30 cases per 100,000 women ${ }^{3}$ and in Santa Catarina state, 2,030 occurrences of $\mathrm{BC}$ are expected ${ }^{3}$. In the state capital, Florianópolis, INCA ${ }^{3}$ estimates there will be 180 new cases of the disease.

Considered mutilating in that it causes functional loss as well as psychic, emotional, social and self-image changes ${ }^{4,5}, \mathrm{BC}$ and its treatment can have a considerable impact on quality of life (QOL) and functional capacity ${ }^{6}$, compromising and decreasing 
the disposition to face these changes ${ }^{7}$. In this respect, investigations in Brazil on improving physical capacities, essential to cope with cancer from diagnosis to recovery ${ }^{7}$, suggested that following a healthy lifestyle is a protective factor against new cancer cases in the country ${ }^{8}$. In addition to being a protective factor, physical activity (PA) may be related to increased life expectancy after BC diagnosis 9 . Accordingly, this study aimed to investigate the relationship between QOL and PA level in women with $\mathrm{BC}$ in the treatment phase.

\section{Methods}

This study, part of a wider investigation entitled "Prostate cancer and breast cancer: physical activity related to quality of life", was approved by the Human Research Ethics Committee (CEPSH) - of Santa Catarina State University (UDESC) (no. 688.548), as well as the Research Ethics Committee of the Oncologic Research Center (CEPON - CEP) in Florianópolis, Santa Catarina state, Brazil (no. 818.174).

The study used a cross-sectional design and non-probability sampling of 158 women with average age of $56.2 \pm 9.4$ years, diagnosed with $\mathrm{BC}$ and submitted to treatment at CEPON between 2014 and 2015. This institution is a reference facility for the treatment of cancer patients in Santa Catarina, as well as a World Health Organization (WHO) reference center for palliative care in Brazil.

The following inclusion criteria were established: being a woman, aged between 40 and 80 years, diagnosed with BC and being in different treatment phases (chemotherapy, radiotherapy, hormone therapy and physiotherapy) at CEPON. Excluded were women classified as illiterate, those undergoing treatment at facilities other than CEPON and those with other types of cancer or metastases of the disease.

Patients were invited to participate in the study after giving their informed consent. Data were collected at an interview via application of a questionnaire at CEPON at a time and day previously scheduled by the researcher in charge, either in the waiting rooms or during chemotherapy treatment. The questionnaire, which was divided into four parts and composed of previously validated instruments, lasted approximately 20 minutes.

Sociodemographic and clinical information: patient characterization in terms of age (40 to 60 years; 61 to 80 years), marital status (single; romantic partner), schooling (elementary; secondary; university) profession before and after diagnosis (up two jobs; retired/disability/unemployed; at home), presence of other diseases (other diseases; no other diseases), number of diseases other than cancer (none; one disease; two or more diseases), recurrence (yes; no), surgical methods (total removal; partial/conservative removal; none) and treatment (chemotherapy; radiotherapy; hormone therapy; physiotherapy), physical consequence - lymphedema (yes; no), self-reported, and weight (kilograms) and height (meters) (self-reported) to calculate body mass index - BMI (weight/height ${ }^{2}$ ). BMI (nutritional status) was classified according to the WHO protocol $(2004)^{10}$ as underweight $(\mathrm{BMI}<18.5)$; normal weight (BMI 18.5 - 24.9); overweight (BMI 25.0 - 29.9); pre-obesity and obesity (BMI $\geq 30.0)$. The underweight and normal weight groups were combined as normal weight and the overweight and obese groups as overweight due to the low number of variables.

The economic stratum, according to the IBGE (Brazilian Institute of Geography and Statistics) $(2010)^{11}$, was divided into five classes: class A, earning at least 20 minimum monthly wages (MW) ( $\approx$ USD 5,600); class B, between 10 and 20 MW ( $\approx$ USD 2,800-5,600); class C, between 4 and 10 MW ( $\approx$ USD 1,120-2,800); class D, between 2 and 4 MW (USD 560-1,120) and class E - up to 2 MW (up to USD 
560). These values correspond to 2014. For statistical purposes the categories were grouped into $(\mathrm{A}+\mathrm{B})$ and $(\mathrm{D}+\mathrm{E})$.

Physical activity, composed of six items, was obtained from the International Physical Activity Questionnaire (IPAQ - short version) ${ }^{12}$, which describes the number of times the individual engaged in labor, domestic, leisure, recreational and sport activities for at least 10 continuous minutes in the previous week, distributed in walking, moderate and vigorous PA. Final classification showed that the women were not sufficiently active, since they engaged in PA for at least 10 continuous minutes but this was not enough to be classified as active. The sum of the duration and frequency of the different activities (walking + moderate + vigorous) classified individuals as follows: active - complied with the recommendations - 1) vigorous $P A \geq 3$ days/week and $\geq 20$ minutes/session; 2) moderate $\geq 5$ days/week and $\geq 30$ minutes /session; 3 ) any sum of activities: $\geq 5$ days/week and $\geq 150 \mathrm{~min} /$ week. The following were considered very active: 1 ) vigorous $\geq 5$ days/ week and $\geq 30 \mathrm{~min} / \mathrm{session} ; 2$ ) vigorous $\geq 3$ days/week and $\geq 20 \mathrm{~min} / \mathrm{session}$ and moderate $\geq 5$ days/week and $\geq 30 \mathrm{~min} / \mathrm{session}$. Due to the low number of participants in the category, the women were grouped into a) sufficiently active as active + very active and $b$ ) not sufficiently active.

Composed of 30 questions, QOL was defined by the European Organization for Research and Treatment of Cancer Quality of Life Questionnaire-C30 (EORTC QLQ-C30) developed by Aaronson et al. ${ }^{13}$, which assesses the QOL of patients with cancer in the four previous weeks. The questionnaire contains Likert scale questions and has been validated for Brazilian women with $\mathrm{BC}^{14}$. The instrument is divided into three scales: functional, with sub- items related to physical, functional, emotional, social, cognitive and role performance aspects; global health status; and symptomatic, related to fatigue, pain, nausea/vomiting, dyspnea, insomnia, loss of appetite, constipation, diarrhea and financial difficulties.

The EORTC QLQ-C30 is complemented by specific cancer modules. The CM - QLQ BR-23 module, also validated in Brazil ${ }^{14}$, was also used. It consists of 23 questions that measure the side effects of chemotherapy, symptoms related to the arm and breast, body image and sexual function, in addition to sexual satisfaction, hair loss and lack of perspectives. The scale and its sub-items are classified from zero to 100, and for the symptom scale values near 100 indicate poor QOL. By contrast, functional and global health values near 100 represent good QOL.

Descriptive statistics were used to calculate the mean, standard deviation and percentage, applying IBM-SPSS Statistics 20.0 software. After data normality was determined by the Kolmogorov-Smirnov test, the following tests were applied: the chi-squared and Fisher's Exact tests to compare the general characteristics of the disease and PA; the Mann-Whitney $\mathrm{U}$ and t-tests to compare QOL and PA, and Spearman's correlation between PA intensity and QOL. All the tests adopted a 95\% significance level.

\section{Results}

Table 1 shows the general characteristics related to the PA of patients with BC. Most of the women were younger than 60 years (69\%), an elementary education level (55.7\%) and overweight (71.8\%). Prior to cancer diagnosis, the majority were working at two jobs (70.3\%), however, after diagnosis, most retired due to disability or unemployment $(57.0 \%)$. The better part of the sample had a romantic partner $(73.4 \%)$ and earned up to four minimum monthly wages (82.3\%). 
TABLE 1 - Sociodemographic characteristics of patients with breast cancer at CEPON, Florianópolis - SC, Brazil. 2014 - 2015 ( $n=158)$.

\begin{tabular}{|c|c|c|c|c|}
\hline Variables & Total \% (95\%Cl) & Not sufficiently active & Active & $p$ \\
\hline Age & & & & $0.716^{* *}$ \\
\hline 40 to 60 years & $69(62-76)$ & 68.1 & 71.1 & \\
\hline 61 to 80 years & $31(24-38)$ & 31.9 & 28.9 & \\
\hline BMI & & & & $0.786^{* *}$ \\
\hline Normal weight & $28.2(21-35)$ & 28.8 & 26.7 & \\
\hline Overweight & $71.8(64-78)$ & 71.2 & 73.3 & \\
\hline Schooling & & & & $0.944^{* *}$ \\
\hline Elementary & $55.7(48-64)$ & 55.8 & 55.6 & \\
\hline Secondary & $32.3(25-40)$ & 32.7 & 31.1 & \\
\hline University & $12.0(7-17)$ & 11.5 & 13.3 & \\
\hline Profession before diagnosis & & & & $0.695^{*}$ \\
\hline Up to two jobs & $70.3(63-77)$ & 68.1 & 75.6 & \\
\hline Retired/disability/unemployed & $10.7(6-16)$ & 11.5 & 8.9 & \\
\hline At home & $19.0(13-25)$ & 20.4 & 15.6 & \\
\hline Profession after diagnosis & & & & $0.831^{* *}$ \\
\hline Up to two jobs & $15.2(10-21)$ & 15.0 & 15.6 & \\
\hline Retired/disability/unemployed & $57.0(49-65)$ & 55.8 & 60.0 & \\
\hline At home & $27.8(21-35)$ & 29.2 & 24.4 & \\
\hline Marital status & & & & $0.346^{* *}$ \\
\hline Single & $26.6(20-34)$ & 46.0 & 37.8 & \\
\hline Romantic partner & $73.4(66-80)$ & 54.0 & 62.2 & \\
\hline Income & & & & $0.579^{*}$ \\
\hline$A+B$ & $3.1(0-6)$ & 2.7 & 4.4 & \\
\hline C & $14.6(9-20)$ & 13.3 & 17.8 & \\
\hline$D+E$ & $82.3(76-88)$ & 84.1 & 77.8 & \\
\hline
\end{tabular}

$\%=$ data frequency; $\mathrm{Cl}=$ con!dence interval; $\mathrm{p}=\mathrm{p}$-value; ${ }^{* *}$ Chi-squared; *Fisher's Exact. BMI - Body mass index; $A+B=A$, earning at least 20 minimum monthly wages (MW) (\# USD 5,600) +; B, between 10-20 MW (\#USD 2,800-5,600); C = between 4-10 MW (\#USD 1,120-2,800); D+E = class D, between 2-4 MW (USD 560-1,120) and; class E, up to 2 MW (up to USD 560).

Table 2 shows the characteristics of $\mathrm{BC}$ and the relation with PA. Most of the not sufficiently active women exhibited no associated disease (56.6\%), in contrast to a majority of the sufficiently active women (53.3\%), with a significant difference between groups. The most common treatment was chemotherapy (34.2\%), showing a significant intergroup difference. Most of the not sufficiently active women were undergoing chemotherapy (41.6\%) and $37.8 \%$ of active individuals hormone therapy.

The data presented in table 3 shows global QOL of $73.7 \pm 25.2$ in women with $\mathrm{BC}$, representing a good level. Two items on the functional scale showed a signifi-

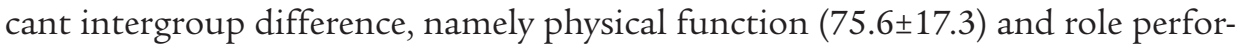
mance (75.2 \pm 30.1 ), with higher values for active women. In relation to the symptom scale, the active women displayed fewer symptoms $(23.8 \pm 19.6)$ than their not sufficiently active counterparts (32.0 \pm 23.2$)$. There was also a significant difference in symptoms related to insomnia and pain, in that the sufficiently active women obtained lower scores.

Table 4 shows the correlations between variables, and although all the associations were weak, there was a positive relationship between both physical function and role performance and PA intensity, indicating that more time spent on walking, moderate PA, moderate + vigorous PA and total PA resulted in better phys- 
ical functionality and role performance. The symptom scale and loss of appetite showed a negative relationship with PA intensity, demonstrating that the more time women with $\mathrm{BC}$ spend on walking, moderate PA, moderate + vigorous PA and total PA, the fewer the symptom-related complaints.

TABLE 2 - Clinical characteristics of the disease in breast cancer patients at CEPON, Florianópolis SC, Brazil $2014-2015(n=158)$.

\begin{tabular}{|c|c|c|c|c|}
\hline Variables & Total \% (95\% Cl) & Not sufficiently active & Active & $p$ \\
\hline Diagnosis of diseases other than $\mathrm{BC}$ & & & & $0.279^{* *}$ \\
\hline Other diseases & $48.7(41-57)$ & 46.0 & 55.6 & \\
\hline No other diseases & $51.3(43-59)$ & 54.0 & 44.4 & \\
\hline Number of diseases other than $B C$ & & & & $0.001^{*}$ \\
\hline None & $51.9(44-60)$ & 56.6 & 40.0 & \\
\hline One disease & $32.3(25-40)$ & 23.9 & 53.3 & \\
\hline Two or more diseases & $15.8(10-22)$ & 19.5 & 6.7 & \\
\hline Recurrence & & & & $0.674^{*}$ \\
\hline Yes & $4.4(1.2-7.7)$ & 5.3 & 2.2 & \\
\hline No & $95.6(92-99)$ & 94.7 & 97.8 & \\
\hline Current treatment & & & & $0.002^{*}$ \\
\hline Chemotherapy & $34.2(27-42)$ & 41.6 & 15.6 & \\
\hline Radiotherapy & $22.2(16-28)$ & 23.9 & 17.8 & \\
\hline Hormone therapy & $26.5(20-34)$ & 22.1 & 37.8 & \\
\hline Physiotherapy & $17.1(11-23)$ & 12.4 & 28.9 & \\
\hline Surgery performed & & & & $0.554^{*}$ \\
\hline Total removal & $57.0(49-64)$ & 54.0 & 64.4 & \\
\hline Partial/conservative removal & $36.7(29-44)$ & 38.9 & 31.1 & \\
\hline None & $6.3(2.4-10)$ & 7.1 & 4.4 & \\
\hline Presence of lymphedema & & & & $0.184^{* *}$ \\
\hline Yes & $47.3(39-55)$ & 43.8 & 55.8 & \\
\hline No & $52.7(45-61)$ & 56.2 & 44.2 & \\
\hline
\end{tabular}

$\%=$ data frequency; $\mathrm{Cl}=$ confidence interval; $\mathrm{p}=\mathrm{p}$-value; ${ }^{* *}$ Chi-squared; ${ }^{*}$ Fisher's Exact. BC - Breast cancer. Bold numbers: statistical significance.

TABLE 3 - Characterization of quality of life according to the physical activity groups of patients with breast cancer at CEPON, Florianópolis - SC, Brazil 2014 - 2015 ( $n=158)$.

\begin{tabular}{lcccc}
\hline \multicolumn{1}{c}{ Variables } & Total & Not sufficiently active & Active & $p$ \\
\hline EORTC QLQ - C30 & & & & \\
\hline Global QOL scale & $83.3(25.0)$ & $75.0(33.3)$ & $83.3(22.9)$ & $0.855^{*}$ \\
\hline Functional scale & $66.7 \pm 21.5$ & $65.3 \pm 22.0$ & $70.3 \pm 19.9$ & $0.172^{* *}$ \\
\hline Cognitive function & $63.3 \pm 33.6$ & $64.9 \pm 31.6$ & $59.3 \pm 38.4$ & $0.343^{* *}$ \\
\hline Emotional function & $60.8 \pm 33.6$ & $60.8 \pm 33.6$ & $60.7 \pm 34.0$ & $0.996^{* *}$ \\
\hline Physical function & $68.3 \pm 21.6$ & $65.4 \pm 22.5$ & $75.6 \pm 17.3$ & $0.007^{* *}$ \\
\hline Social function & $78.1 \pm 29.9$ & $76.4 \pm 31.8$ & $82.2 \pm 24.5$ & $0.271^{* *}$ \\
\hline Role performance & $66.7 \pm 36.1$ & $63.3 \pm 37.8$ & $75.2 \pm 30.1$ & $0.040^{* *}$ \\
\hline Symptom scale & $15.4(30.8)$ & $46.2(52.6)$ & $15.4(22.4)$ & $0.048^{*}$ \\
\hline Fatigue & $22.2(55.6)$ & $55.6(72.2)$ & $22.2(44.4)$ & $0.056^{*}$ \\
\hline Loss of appetite & $0.0(33.3)$ & $0.0(66.7)$ & $0.0(33.3)$ & $0.005^{*}$ \\
\hline Insomnia & $33.3(100.0)$ & $66.7(100.0)$ & $33.3(91.7)$ & $0.666^{*}$ \\
\hline Pain & $16.7(66.7)$ & $50.0(83.3)$ & $16.7(62.6)$ & $0.040^{*}$ \\
\hline Nausea and vomiting & $0.0(16.7)$ & $0.0(58.3)$ & $0.0(25.0)$ & $0.064^{*}$ \\
\hline Continue... & & & &
\end{tabular}

Continue... 
... continue

\begin{tabular}{lcccc}
\hline Dyspnea & $0.0(33.3)$ & $0.0(83.3)$ & $0.0(33.3)$ & $0.618^{*}$ \\
\hline Constipation & $0.0(33.3)$ & $0.0(50.0)$ & $33.3(58.3)$ & $0.491^{*}$ \\
\hline Diarrhea & $0.0(0.0)$ & $0.0(0.0)$ & $0.0(0.0)$ & $0.785^{*}$ \\
\hline Financial difficulties & $33.3(100.0)$ & $66.7(100.00)$ & $0.00(83.3)$ & $0.836^{*}$ \\
\hline EORTC QLQ - BR23 & & & \\
\hline Functional scale & $66.3 \pm 22.5$ & $67.9 \pm 22.0$ & $62.2 \pm 23.5$ & $0.149^{* *}$ \\
\hline Body image & $75.0(58.3)$ & $58.3(54.2)$ & $50.0(54.2)$ & $0.394^{*}$ \\
\hline Sexual function & $50.0(33.3)$ & $50.0(25.0)$ & $41.7(16.7)$ & $0.071^{*}$ \\
\hline Sexual satisfaction & $66.7(33.3)$ & $66.7(83.3)$ & $66.7(50.0)$ & $0.732^{*}$ \\
\hline Future perspective & $0.0(66.7)$ & $0.0(66.7)$ & $0.0(66.7)$ & $0.391^{*}$ \\
\hline Symptom scale & $38.3(21.6)$ & $38.7(21.9)$ & $37.2 \pm 21.2$ & $0.695^{* *}$ \\
\hline Treatment effects & $36.6 \pm 24.1$ & $36.2 \pm 23.8$ & $37.4 \pm 25.2$ & $0.794^{* *}$ \\
\hline Breast symptoms & $34.9 \pm 28.5$ & $35.7 \pm 28.1$ & $32.8 \pm 29.6$ & $0.563^{* *}$ \\
\hline Arm symptoms & $44.1 \pm 33.9$ & $44.5 \pm 34.7$ & $43 \pm 32.0$ & $0.792^{* *}$ \\
\hline Hair loss & $49.4 \pm 47.2$ & $52.5 \pm 45.8$ & $42.6 \pm 50.9$ & $0.412^{*}$ \\
\hline
\end{tabular}

$\overline{\mathrm{x}}(\mathrm{sd})=$ mean (standard deviation); $\mathrm{p}=\mathrm{p}$-value; $\mathrm{QOL}$ = quality of life; * $\mathrm{p}$-value obtained in the Mann-Whitney $U$ test; and variable presented as mean and interquartile interval ${ }^{* *} p=$ value obtained in the independent samples t-test; and variable presented as mean $(\bar{x})$ and standard deviation $( \pm)$. Bold numbers: statistical significance.

TABLE 4 - Relationship between physical activity and quality of life of patients with breast cancer at CEPON, Florianópolis - SC, Brazil 2014 - 2015.

\begin{tabular}{lccccc}
\hline \multicolumn{1}{c}{ Variables } & $\begin{array}{c}\text { Walking } \\
\text { (min/day) }\end{array}$ & $\begin{array}{c}\text { Mod PA } \\
\text { (min/day) }\end{array}$ & $\begin{array}{c}\text { Vig PA } \\
\text { (min/day) }\end{array}$ & $\begin{array}{c}\text { Mod+vig PA } \\
\text { (min/day) }\end{array}$ & $\begin{array}{c}\text { Total PA } \\
\text { (min/day) }\end{array}$ \\
\hline Physical function & $0.23^{* *}$ & $0.16^{*}$ & 0.07 & $0.16^{*}$ & $0.23^{* *}$ \\
\hline Role performance & $0.19^{*}$ & 0.14 & 0.09 & 0.14 & $0.23^{* *}$ \\
\hline Symptom scale & $-0.20^{*}$ & $-0.21^{* *}$ & 0.01 & $-0.21^{* *}$ & $-0.24^{* *}$ \\
\hline Loss of appetite & $-0.25^{* *}$ & $-0.20^{*}$ & -0.06 & $-0.19^{*}$ & $-0.25^{* *}$ \\
\hline
\end{tabular}

min/day = minutes per day; Mod PA = moderate physical activity; Vig PA = vigorous physical activity; Mod+vig PA = moderate + vigorous physical activity; Total PA= total physical activity. Spearman's correlation test: * Significant correlation 0.05. ** Significant correlation 0.01 .

\section{Discussion}

This study aimed to investigate the relationship between QOL and PA in women with $\mathrm{BC}$ undergoing treatment at $\mathrm{CEPON}$ in the city of Florianópolis, Santa Catarina state. Most of the patients were not sufficiently active and obtained good global QOL scores, a positive association with physical function and role performance and a negative correlation with the symptom scale and loss of appetite with increasing PA.

Despite the fact that leisure, domestic and total physical activity may exert a protective effect on the risk of $\mathrm{BC}$ in pre and postmenopause $\mathrm{e}^{15}$ and that the physically active population, previously diagnosed with cancer, would be clinically associated with important health-related benefits for $\mathrm{QOL}^{16}, 71.5 \%$ of the women in the present study did not comply with the 150 minutes of moderate to vigorous PA for patients with BC recommended by the American College of Sports Medicine ${ }^{17}$.

One of the plausible reasons for this finding is the larger number of not sufficiently active women with BC undergoing chemotherapy (41.6\%). The literature reports that patients submitted to chemotherapy exhibit physical and emotional side effects ${ }^{18,19}$. Moreover, studies also found that the patients themselves noted considerable changes in QOL and in the physical, emotional and social aspects of daily and family activities, due to the disease and its treatment ${ }^{20-22}$. It was also 
found that chemotherapy had a direct effect on decreasing the PA levels of patients with BC up to eight months after diagnosis ${ }^{23}$.

Women with BC associated chemotherapy with their abandonment of occupational activities due to the increasingly aggressive side effects ${ }^{24}$. This finding is likely due to the number of women with BC who retired, were unemployed or on disability leave after diagnosis of the disease (57\%). Oberst et al. ${ }^{25}$ report that the inability of women with $\mathrm{BC}$ to work could persist one year or more after treatment.

Tipples and Robinson ${ }^{26}$ state that the most widely reported symptoms are pain, fatigue and emotional stress, which can last for months or even years after treatment. Physical activity may help decrease post-surgical pain, since breast tissue may be partially or totally removed during the process, thereby causing more complaints related to this symptom ${ }^{27}$.

Although no significant difference was observed between PA and role performance in the QOL of $\mathrm{BC}$ survivors $^{28}$, the present study found that QOL-related role performance obtained a significant difference between active women (75.2 \pm 30.1$)$ and their not sufficiently active counterparts $(63.3 \pm 37.8)$, indicating that insufficient PA decreases the role performance ability in these women. It was also shown that the role performance of women with $\mathrm{BC}$ who engaged in walking and total PA exhibited positively correlated albeit weak values, corroborating the findings of Mandelblatt et al. ${ }^{6}$, since the women with BC that displayed higher PA levels generally had better QOL.

Also in the present study, the active patients showed physical function measures closer to 100 than the not sufficiently active. According to Soares ${ }^{7}$, among other things, PA improves the basic physical capacities needed to cope with cancer, from diagnosis to recovery. Physical function exhibited a positive relationship with walking, moderate PA, moderate + vigorous PA and total PA in the women of the present study. According to Basen-Engquist et al. ${ }^{29}$, the duration of PA may be related to better physical functioning in BC survivors.

Given the above and knowing that PA enhances a number of aspects for patients with cancer ${ }^{7,29}$, researchers have analyzed the use of new strategies, such as cell phone apps $^{30}$. It is important to underscore the importance of follow-up to prolong the results of intervention and that patients continue to engage in PA after treatment. Physical activity is also essential during the different types of clinical treatment, such as chemotherapy, radiotherapy and hormone therapy, given all the benefits for $\mathrm{QOL}^{6}$, as demonstrated by the findings of the present study. It is recommended that health professionals prescribe PA in the treatment of $\mathrm{BC}$, as well as in the post-treatment period, thereby helping patients resume their daily and occupational activities.

The study limitations are the self-reported interview, due to non-access to the patients' medical charts. Although the IPAQ questionnaire - short version is widely used in national and international studies ${ }^{9}$, it allows only subjective responses with respect to PA, and the type of study (cross-sectional) precludes establishing a long-term relationship, causal or not. Furthermore, the sample selection can be considered a limitation, since it involved convenience sampling, as well as the patient-interviewer relationship, because, despite the fact that the group was qualified to collect data, these were purely numerical and quantitative in nature. This is because the feelings conveyed in the responses could not be adequately incorporated into the numerically-based categorization provided by the instrument. Despite being aware of their situation at the time, more than merely emotions, the accounts of the $\mathrm{BC}$ patients raised questions and situations for which there were sometimes no words of comfort to ease their anguish and uncertainties, which 
cannot be reproduced in this quantitative study.

It can be concluded that most of the women with $\mathrm{BC}$ in the study were not sufficiently active, exhibiting worse physical function and role performance scores, compared to the active patients. Furthermore, inversely proportional values were found on the symptom scale and loss of appetite, indicating that active women with $\mathrm{BC}$ exhibited better QOL and a positive association with PA when compared to the not sufficiently active. Women with higher moderate and vigorous PA levels also displayed better QOL ${ }^{6}$. Furthermore, PA was associated with improved QOL during the $\mathrm{BC}$ treatment phase of these women ${ }^{6}$.

Given that PA can improve health and $\mathrm{QOL}^{17}$, public and private institutions should pay more attention to promoting physical activities in this population, and additional studies should be conducted, primarily in Brazil, for the prevention and treatment of BC.

\section{Contribution of authors}

M. Ribovski (0000-0001-5368-9401) participated in the study design, data collection, tabulation, data analysis, discussion of the results, manuscript writing and critical review of the final version; L. Boing (0000-0003-4978-9703) participated in the study design, data collection, tabulation and data analysis, results interpretation and discussion, manuscript writing and critical review of the final version; $F$. F. Sperandio (0000-0002-2435-0246), M. Dias (0000-0002-2109-3563) and N. M. Reis (0000-0002-3925-9357) participated in the results interpretation and discussion, and manuscript writing; A. C. A. Guimarães (0000-0001-5167-2921) participated in the study design, critical review and orientation of the research project, data analysis, discussion of results, writing and critical review of the final version.

\section{Conflicts of interest}

The authors declare no conflict of interest.

\section{References}

1. Castro R. Câncer na mídia: uma questão de saúde pública. Rev Bras Cancerol. 2009; 55(1):41-9.

2. Ferlay J, Soerjomataram I, Ervik M, Dikshit R, Eser S, Mathers C, et al. GLOBOCAN 2012, Cancer Incidence and Mortality Worldwide: IARC Cancer Base No. 11 [online]. Lyon, France: International Agency for Research on Cancer; 2013. [citado 2014 oct 09]. Disponível em: url:http://globocan.iarc.fr.

3. Instituto Nacional De Câncer José Alencar Gomes Da Silva. Coordenação Geral de Prevenção e Vigilância. Estimativa 2016 - Incidência De Câncer No Brasil. Rio de Janeiro: Instituto Nacional de Câncer José Alencar Gomes da Silva; 2015.

4. Makluf ASD, Dias RC, Barra AA. Avaliação da qualidade de vida em mulheres com câncer da mama. Rev Bras Cancerol. 2006;52(1):49-58.

5. Soares PBM, Carneiro JA, Rocha LA, Gonçalves RCR, Martelli DRB, Fagundes M, et al. The quality of life of disease-free Brazilian breast cancer survivors. Rev Esc Enferm USP. 2013;47(1):69-75.

6. Mandelblatt JS, Luta G, Kwan ML, Makgoeng SB, Ergas IJ, Roh JM, et al. Associations of physical activity with quality of life and functional ability in breast cancer patients during active adjuvant treatment: the Pathways Study. Breast Cancer Res Treat. 2011;129(2):521-9.

7. Soares WTE. Parâmetros, considerações e modulação de programas de exercício físico para pacientes oncológicos: uma revisão sistemática. Rev Bras Med Esp. 2011;17(4):284-9.

8. Instituto Nacional de Câncer José Alencar Gomes da Silva. Síntese de Resultados e Comentários. Rio de Janeiro: Instituto Nacional do Câncer José Alencar Gomes da Silva; 2010.

9. Sabino NM, Moreira JR, Resende V, Ferreira LM. Nível de atividade física em mulheres mastectomizadas e submetidas a reconstrução mamária. Rev Bras Cir Plást. 2012;27(4):556-61. 
10. World Health Organization. The International Classifcation of adult underweight, overweight and obesity according to BMI. World Health Organization; 2004.

11. Instituto Brasileiro de Geografia e Estatística. Programa Nacional de Amostra por Domicílio. Distrito Federal: Instituto Brasileiro de Geografia e Estatística; 2010.

12. Pardini R, Matsudo S, Matsudo V, Araújo T, Andrade E, Braggion G, et al. Validation of International Physical Questionnaire (IPAQ): pilot study in Brazilian young adults. Med Sci Sports Exerc. 1997;29(6):S5-S9.

13. Aaronson NK, Ahmedzai S, Bergman B, Bullinger M, Cull A, Duez NJ, et al. The European Organization for Research and Treatment of Cancer QLQ-C30: A quality-oflife instrument for use in international clinical trials in oncology. J Natl Cancer Inst. 1993;85(5):365-76.

14. Michels FAS, Latorre MRO, Maciel MS. Validity, reliability and understanding of the EORTC-C30 and EORTC-BR23, quality of life questionnaires specific for breast cancer. Rev Bras Epidemiol. 2013;16(2):352-63.

15. Lahmann PH, Friedenreich C, Schuit AJ, Salvini S, Allen NE, Key TJ, et al. Physical activity and breast cancer risk: the European Prospective Investigation into Cancer and Nutrition. Cancer Epidemiol Biomarkers Prev. 2007;16(1):36-42.

16. Vallance JK, Lavallee CM, Culos-Reed NS, Trudeau MG. Physical activity is associated with clinically important differences in health-related quality of life among rural and small-town breast cancer survivors. Support Care Cancer. 2012;20(5):1079-87.

17. ACSM. American College of Sports Medicine. ACSM's Resource Manual for Guidelines for Exercise Testing and Prescription. Philadelphia: Lippincott Williams \& Wilkins; 2010.

18. Ferguson RJ, Riggs R, Ahles T, Saykin AJ. Management of chemotherapy-related cognitive dysfunction. In: Feuerstein M (ed). Handbook of Cancer Survivorship. New York: Springer; 2007. p. 287-301.

19. Vardy J, Tannock I. Cognitive function after chemotherapy in adults with solid tumors. Crit Rev Onclol/Hemotol. 2007;63(3):183-202.

20. Akin S, Can G, Durna Z, Aydiner A. The quality of life and self-efficacy of Turkish breast cancer patients undergoing chemotherapy. Eur J Oncol Nurs. 2008;12(5):449-56.

21. Browall M, Ahlberg K, Karlsson P, Danielson E, Persson LO, Gaston-Johansson F. Healthrelated quality of life during adjuvant treatment for breast cancer among postmenopausal women. Eur J Oncol Nurs. 2008;12(3):180-89.

22. Fangel LMV, Panobianco MS, Kebbe LM, Almeida AM, Gozzo TO. Qualidade de vida e desempenho de atividades cotidianas após tratamento das neoplasias mamárias. Acta Paul Enferm. 2013;26(1):93-100.

23. Kwan ML, Sternfeld B, Ergas IJ, Timperi AW, Roh JM, Hong CC, et al. Change in physical activity during active treatment in a prospective study of breast cancer survivors. Breast Cancer Res Treat. 2012; 131(2): 679-90

24. Martins LC, Ferreira Filho C, Giglio AD, Munhoes DA, Trevizan LLB, Herbst LG, et al. Desempenho profissional ou doméstico das pacientes em quimioterapia para câncer de mama. Rev Assoc Med Bras. 2009;55(2):158-62.

25. Oberst K, Bradley CJ, Gardiner JC, Schenk M, Given CW. Work task disability in employed breast and prostate cancer patients. J Cancer Surviv. 2010; 4(4):322-30.

26. Tipples K, Robinson A. Optimal management of cancer treatment-induced bone loss: considerations for elderly patients. Drugs Aging. 2011;28:867-83.

27. Hoffman L. How to Keep Your Patients Moving. J Support Oncol. 2006;4:153-8.

28. Mohammadi S, Sulaiman S, Koon PB, Amani R, Hosseini SM. Impact of healthy eating practices and physical activity on quality of life among breast cancer survivors. Asian Pacific J Cancer Prev. 2012;(14):481-7.

29. Basen-Engquist K, Hughes D, Perkins H, Shinn E, Taylor CC. Dimensions of physical activity and their relationship to physical and emotional symptoms in breast cancer survivors. J Cancer Surviv. 2008;2(4):253-61.

30. Lyons EJ et al. Testing the effects of narrative and play on physical activity among breast cancer survivors using mobile apps: study protocol for a randomized controlled trial. BMC Cancer 2016, 16(1):1.

Corresponding Author

Marina Ribovski

marinaribovski@gmail.com
Rua General Estilac Leal, 129, bl D

apto 208, Coqueiros. CEP: 88080760

Florianópolis, SC. Brazil

Tel.: (48) 99834-7252
Received

Revised

$18 / 02 / 2016$

$19 / 08 / 2016$

$25 / 03 / 2017$

Approved $\quad 06 / 04 / 2017$ 